\title{
Performance measurement of Tempeh crackers supply chain management using Halal criteria on SCOR Model
}

\author{
Dini Wahyuni ${ }^{1, *}$, Nazaruddin ${ }^{1}$, Suci Amalia Frastika ${ }^{1}$, and Irwan Budiman ${ }^{2}$ \\ ${ }^{1}$ Industrial Engineering Department, Universitas Sumatera Utara, Almamater Kampus USU Medan, \\ Indonesia \\ ${ }^{2}$ Industrial Engineering Department, Universitas Prima Indonesia, Almamater Kampus USU Medan, \\ Indonesia
}

\begin{abstract}
Currently, the Indonesian business world is still dominated by Small and Medium Enterprises (SME). The number of SME has reached more than 26 million businesses, with Sumatera Utara being the province with the fourth largest number of SME in Indonesia. Every SME that produces halal products needs to measure its production performance by considering halal criteria to find out and measure the implementation of Islamic principles in product processing. There are 15 Key Performance Indicators used in measuring performance with SCOR Model and 6 of them are related to halal, namely Halal MUI label, Halal raw material, Order received damage free, Accuracy payment to suppliers, Appropriate in paying salaries, and number of defective products. Final performance of Tempeh SME is 45.94; which shows the performance of SME is still in a marginal condition. Based on the identification with the traffic light system, out of 15 KPIs (Key Performance Indicators) there are 7 KPIs that have a red color which indicates that repairing efforts are needed, namely: meetings with customers, MUI halal labels, number of defective products, flexibility in product manufacturing, equipment life, complain rate, and product replacement time.
\end{abstract}

\section{Introduction}

Performance measurement is the company's ability to set the standards desired by customers by considering low production and maintenance costs, improving product quality, reducing work-in-process inventory, reducing material handling costs and deadlines for delivery. [1]

To provide cheap and good quality products, supply chain management is the key to determining a company's competitive advantage. However, in practice, management is faced with uncertainty in demand, supply (delivery lead time, price, quality of raw materials, etc.), and internals party (machine failure, imperfect machine performance, production quality, etc.). [2]

\footnotetext{
* Corresponding author: diniwahyuni@gmail.com
} 
Indonesia is one of the predominantly Muslim countries. Based on data from Global Religious Futures, the Muslim population in Indonesia is around $87 \%$ of Indonesia's population. Report from the State of The Global Islamic Economy for 2016-2017 shown the halal food industry has the largest estimated revenue in 2021 , namely 1.9 trillion, with Indonesia in first place for consumers of halal food products, amounting to \$ 154.9 billion. A Muslim is obliged to ensure that the food he consumes is halal. Halal is something that is allowed by the Shari'a to be done, used, or endeavoured [3].

The Indonesian government is obliged to ensure that food circulating in Indonesia can be recognized as halal or haram, which the government enforces legislation No. 33 in year 2014 concerning the guarantee of halal products. With the enactment of this law, every food and beverage product that is traded and distributed to the wider community must be certified halal. Article 67 of the legislation explains that the obligation to be certified for products circulating and traded will take effect from five years since the Law was passed, meaning that in 2019 in October all products traded and circulated must be halal certified, including SME products. The government through the Badan Penyelenggara Jaminan Produk Halal (BPJPH- an organizing agency for halal product assurance in Indonesia) has the authority to carry out halal certification, while LPPOM MUI is a Halal Inspection Agency. Since the enactment of this Law, in 2024 there will be sanctions for business actors who violate the Law. Violations against business actors who do not maintain the halal status of products that have obtained a halal certificate are punished with a maximum imprisonment of five years or a maximum fine of Rp. 2 billion. (Article 56, legislation No. 33 in year 2014) [4]

To ensure the halal status of the final product that is ready for consumption, every link in the halal supply chain must apply a halal guarantee system. The halal assurance system is an integrated management system that is prepared, implemented and maintained by companies to regulate materials, production processes, products, human resources and procedures in order to maintain the continuity of the halal production process in accordance with the requirements. There are 11 criteria that must be in the guarantee halal system, namely: 1) Halal policy, 2) Halal management team, 3) Training and education, 4) Materials, 5) Products, 6) Production facilities, 7) Written procedures for critical activities, 8) Tracebility, 9 ) Procedures for handling products that do not confirm the criteria, 10) Internal audit, 11) Management Review [5]. Halal supply chain management is a halal network management that aims to expand the integrity of halal from the source to the point of purchase of consumers. [6], so that every SME that produces halal products needs to measure the performance of their supply chain management by considering halal criteria from upstream to downstream. Performance measurement can be done using the SCOR method approach. The SCOR (Supply Chain Operation Reference) method is a method in evaluating supply chain performance, from purchasing raw materials to products reaching consumers.

Performance appraisal using the SCOR method has been carried out in the potato chip industry by measuring each activity in the company's business processes in detail from upstream to downstream [7]. The application of the SCOR method in halal manufacturing has also been studied with indicators of product halal certification, halal raw materials, and price determination [8].

This research was conducted at the Tempeh crackers industry, where the owner of the SME stated that the tempeh crackers they produced were halal. This SME has never done a performance measurement, so this study aims to measure the performance of supply chain management in SME Tempeh crackers using the SCOR and AHP methods based on halal criteria. 


\section{Research methods}

The research variable is a Key Performance Indicator (KPI) obtained from previous research references, and adjusted to the company's business processes. Data collection was carried out through interviews with SME owners, direct observation of the state of SME, distributing AHP questionnaires, and literature study [9]. Data processing was carried out using the adoption of the SCOR model, namely: 1) Normalization of the norm de boer, 2) Weighting of AHP (Analytical Hierarchy Process), 3) Calculation of the final weight of the supply chain, 4) Calculation of the overall performance of the supply chain [10].

\section{Results and discussion}

\subsection{Flow of Supply Chain Activities in SME Tempeh crackers}

The flow of supply chain activities for the Tempeh Crackers can be seen in Figure 1.

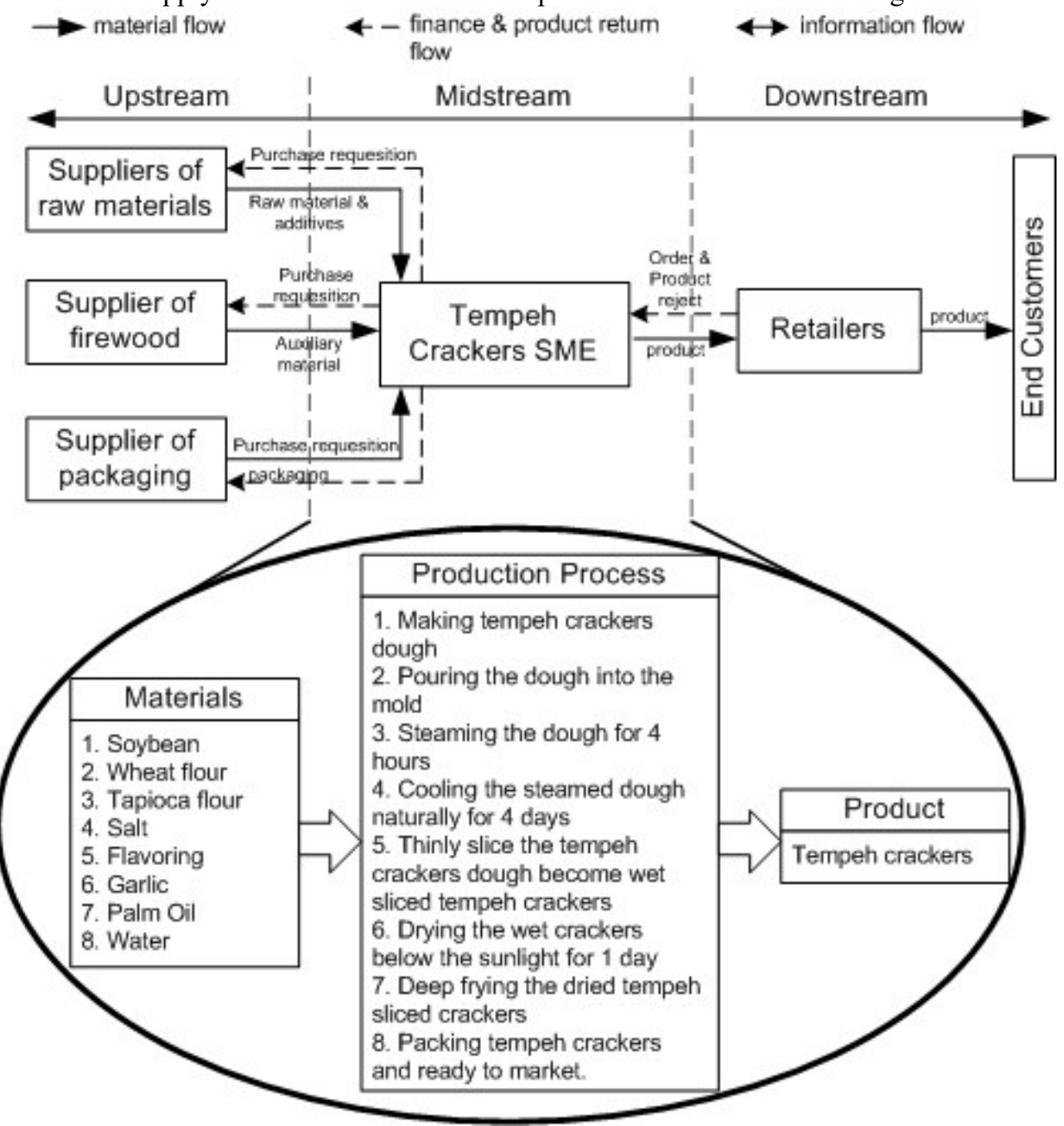

Fig. 1. Flow of Supply Chain Activities for Tempeh Crackers in SME 


\section{Supplier Activities}

This SME buys raw materials and additional materials at shops in Pajak Baru, Stabat while the plastic (wrapping) crackers are obtained from Toko Mira in Binjai City. Firewood is obtained directly from wood sellers located around SME.

2. Manufacture activity

This SME makes tempeh crackers every day, the manufacturing activities of this SME include the following activities: 1) Making tempeh cracker dough. 2) Pouring into the mold. 3) Steaming the tempeh cracker dough. 4) Cooling 5) Slicing tempeh crackers 6) Drying in the sun 7) Frying tempeh crackers 8) Packing tempeh crackers.

Each time they are made using $80 \mathrm{~kg}$ of soybean as raw material, and it produces 3200 packages of crackers in plastic packaging.

\section{Retailer Activity}

These SME products are sold in shops and agents around the SME, in Binjai City, and shops near the Mercy tourist spot, on the outskirts of Medan City.

\subsection{Mapping of Supply Chain Activities using the SCOR Method in SME Tempeh crackers}

In Table 1, it shown the activities found in the supply chain for tempeh crackers using the SCOR approach.

Table 1. Mapping of Crackers Tempeh Supply Chain Activities with the SCOR Approach

\begin{tabular}{|r|l|l|}
\hline No & Basic Process & Activities \\
\hline 1 & Plan & $\begin{array}{l}\text { This activity includes planning for the production of tempeh } \\
\text { crackers including planning for raw material supplies, planning } \\
\text { for production, and planning for marketing. }\end{array}$ \\
\hline 3 & Make & $\begin{array}{l}\text { This activity includes the process of procuring raw materials for } \\
\text { the production of tempeh crackers to meet market needs. These } \\
\text { activities include: scheduling and shipping, receiving, checking, } \\
\text { making payments to suppliers, and assessing the performance } \\
\text { of suppliers. }\end{array}$ \\
\hline 4 & $\begin{array}{l}\text { This activity includes the processes of transforming products } \\
\text { from raw materials to products. The stages of the process are: } \\
\text { 1. Making tempeh crackers dough } \\
\text { 2. Pouring the dough into the mold } \\
\text { 3. Steaming the dough for 4 hours } \\
\text { 4. Cooling the steamed dough naturally for 4 days } \\
\text { 5. Thinly slice the tempeh crackers dough become wet sliced } \\
\text { tempeh crackers } \\
\text { 6. Drying the wet crackers below the sunlight for 1 day } \\
\text { 7. Deep frying the dried tempeh sliced crackers } \\
\text { 8. Packing crackers and ready to market tempeh. }\end{array}$ \\
\hline 5 & $\begin{array}{l}\text { These activities include marketing of tempeh crackers to } \\
\text { consumers, starting from processing order requesition, quoting } \\
\text { prices, delivering crackers, and making payments from } \\
\text { consumers. }\end{array}$ \\
\hline Return & $\begin{array}{l}\text { This activity includes returning crackers from customers who } \\
\text { have not sold for more than 2 weeks, or when the quality has } \\
\text { decreased. }\end{array}$ \\
\hline
\end{tabular}




\subsection{Determination of Key Performance Indicators (KPI)}

The determination of KPI is carried out by considering related references, including Harwati (2019), namely indicators: MUI Halal label, halal raw material, accurate payment to supplier, appropriate in paying salaries, and complaint rate [8]. From Prasetya (2019) research on potato chip SME, indicators are used: meeting with customers, lead time for ordering materials, number of defective products, product manufacturing cycle time, flexibility in manufacturing finished products, equipment life, sales time, delivery of finished products, replacement time. Product [7]. From Wahyuniardi (2017) adopted the order damage free KPI [11].

From the references above and in accordance with the company's business processes, 15 KPIs were obtained which will be used as performance indicators:

1. MUI halal label: representation of tempeh crackers has MUI halal certificate. This KPI is an attribute of reliability in the plan process as proof of the company's commitment to producing halal products.

2. Meetings with customers: schedule meetings with customers to get voice of customers. This KPI is an attribute of responsiveness in the Plan process because it relates to the responsibility for hearing consumer complaints.

3. Halal raw material, the use of halal ingredients in making tempeh crackers. This KPI includes the attribute of reliability in the source process, because it is related to reliability in the provision of halal materials to produce halal products.

4. Order received damage free: describes the percentage of damaged materials from suppliers. This KPI includes the reliability attribute in the source process because it shows the reliability of SME in maintaining the quality of the materials to be used.

5. Lead time for ordering materials: this KPI includes the responsiveness attribute in the source process, because it relates to how quickly the material arrives so that it can be processed.

6. Accuracy payment to supplier: the percentage of on time payments to suppliers. This KPI includes the responsiveness attribute in the source process. The sooner the payment is made the better.

7. Appropriate in paying salaries, the percentage of accuracy in paying employee salaries. This KPI includes the responsiveness attribute in the source process because it shows the company's responsibility for the services it receives.

8. The number of defective products, shows the percentage of reject products. This KPI includes the reliability attribute in the make process, related to the reliability of minimizing reject products.

9. Production cycle time, time to produce a product. This KPI includes the responsiveness attribute in the make process, related to the speed of producing the product.

10. Flexibility of manufacturing finished products, the percentage increase in demand that can be met. This KPI includes the agility attribute in the make process.

11. Equipment lifetime, percentage of equipment life time used. This KPI includes asset attributes in the make process, related to the assets owned by SME.

12. Sales timeframe, timeframe for marketing the finished product (which has been packaged). This KPI includes the responsiveness attribute in the deliver process.

13. Delivery of finished products, the percentage of ability to deliver products according to consumer demand. This KPI includes the reliability attribute in the deliver process, which relates to the reliability of product delivery according to the desired quantity and time. 
14. Complaint rate: percentage of customer complaints. This KPI includes the reliability attribute in the return process, because it shows the reliability of minimizing customer complaints.

15. Product replacement time, the time it takes to replace the product. This KPI includes the responsiveness attribute in the return process, which relates to how quickly the producer can replace the product returned.

The KPI hierarchy can be seen in Figure 2.

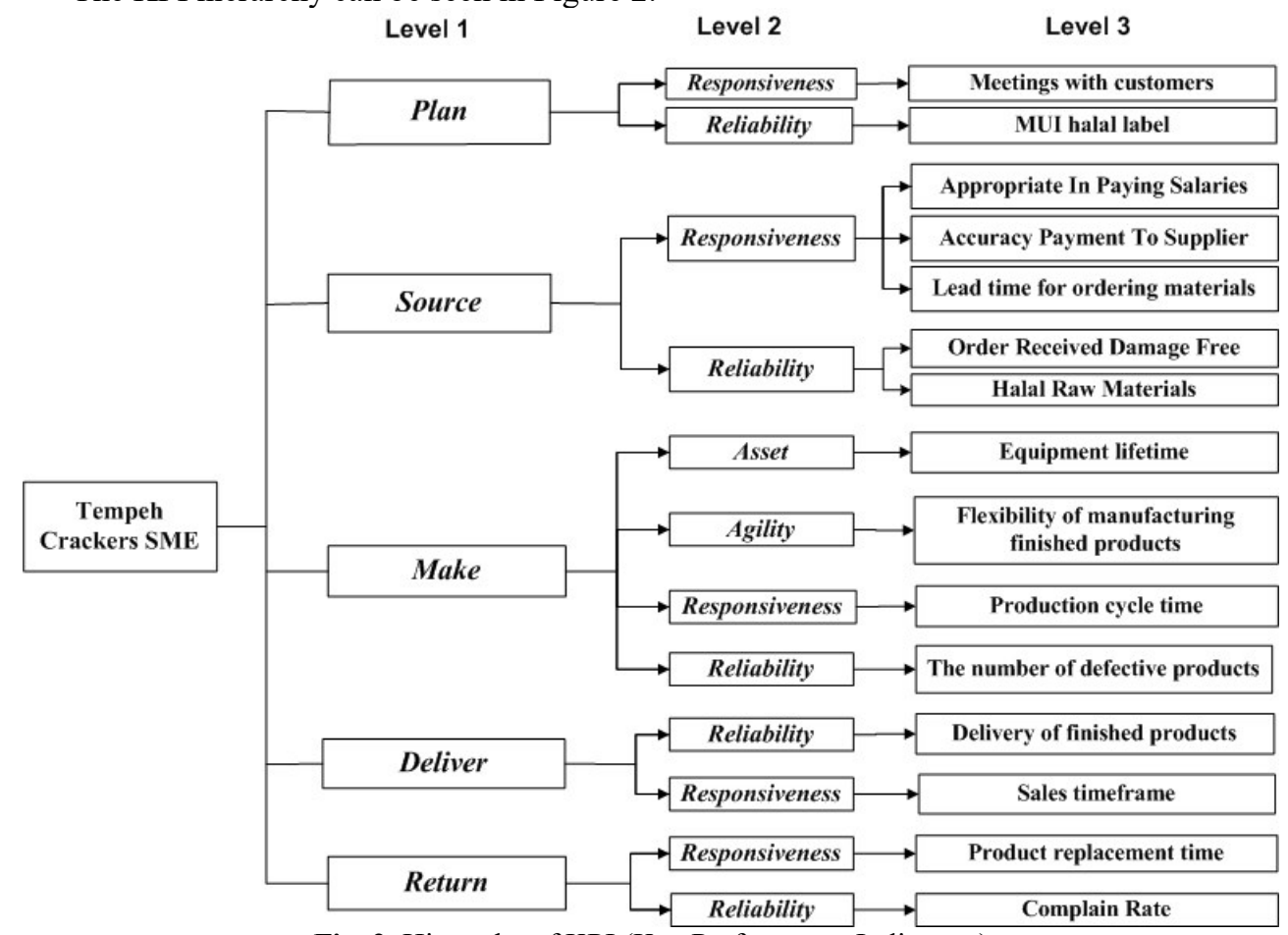

Fig. 2. Hierarchy of KPI (Key Performance Indicators)

\subsection{Calculation of Snorm De Boer Normalization}

Normalization plays an important role in achieving the final value of performance measurement. Each indicator has a different weight with different scale sizes. [12].

The normalization process is carried out with the Snorm De Boer normalization formula, namely:

a. Larger is better category

$$
\operatorname{Snorm}(\text { skor })=\frac{S I-S_{\min }}{S_{\max }-S_{\min }} \times 100
$$

b. Lower is better category

$$
\operatorname{Snorm}(\text { skor })=\frac{S_{\max }-S I}{S_{\max }-S_{\min }} \times 100
$$


Description :

$\mathrm{SI}=$ actual indicator value that was successfully achieved

$\mathrm{Smin}=$ The worst performance score from the performance indicator

Smax $=$ The best performance value from the performance indicator

For example: in the KPI the number of defective products, during the cracker production process in SME, the number of crackers destroyed is around $1 \mathrm{~kg}$, so that the worst value of this KPI is assumed to be $1.5 \mathrm{~kg}$, and the best value is $0 \mathrm{~kg}$ (lower is better). Then Snorm:

$$
\operatorname{Snorm}(\text { skor })=\frac{S_{\max }-S I}{S_{\max }-S_{\min }} \times 100=\frac{1.5-1.0}{1.5-0} \times 100=33.33
$$

The recapitulation of KPI (Key Performance Indicators) normalization scores can be seen in Table 2.

Table 2. Recapitulation of KPI Normalized Scores (Key Performance Indicators)

\begin{tabular}{|c|c|c|c|c|}
\hline KPI & Attributes & $\begin{array}{l}\text { Basic } \\
\text { Process }\end{array}$ & Category & $\begin{array}{l}\text { Norm } \\
\text { Score }\end{array}$ \\
\hline MUI Halal Label & Reliability & \multirow[t]{2}{*}{ Plan } & Larger is better & 0,00 \\
\hline Meeting with Customers & Responsiveness & & Larger is better & 0,00 \\
\hline Halal Raw Materials & \multirow[t]{2}{*}{ Reliability } & \multirow[t]{5}{*}{ Source } & Larger is better & 71,42 \\
\hline $\begin{array}{l}\text { Order Received Damage } \\
\text { Free }\end{array}$ & & & Lower is better & 100,00 \\
\hline $\begin{array}{l}\text { Lead time for ordering } \\
\text { materials }\end{array}$ & \multirow[t]{3}{*}{ Responsiveness } & & Lower is better & 91,30 \\
\hline $\begin{array}{l}\text { Accuracy Payment To } \\
\text { Supplier }\end{array}$ & & & Larger is better & 100,00 \\
\hline $\begin{array}{l}\text { Appropriate In Paying } \\
\text { Salaries }\end{array}$ & & & Larger is better & 100,00 \\
\hline $\begin{array}{l}\text { Number of defective } \\
\text { products }\end{array}$ & Reliability & \multirow[t]{4}{*}{ Make } & Lower is better & 33,33 \\
\hline Production cycle time & Responsiveness & & Lower is better & 99,80 \\
\hline $\begin{array}{l}\text { Flexibility in the } \\
\text { manufacture of finished } \\
\text { products }\end{array}$ & Agility & & Larger is better & 50,00 \\
\hline Equipment life & Asset & & Larger is better & 50,00 \\
\hline $\begin{array}{l}\text { Delivery of finished } \\
\text { products }\end{array}$ & Responsiveness & \multirow[t]{2}{*}{ Deliver } & Larger is better & 82,60 \\
\hline Sales timeframe & Reliability & & Lower is better & 100,00 \\
\hline Complain Rate & Reliability & \multirow[t]{2}{*}{ Return } & Lower is better & 60,00 \\
\hline Product Replacement Time & Responsiveness & & Lower is better & 50,00 \\
\hline
\end{tabular}

\subsection{AHP (Analytical Hierarchy Process) Weighting}

AHP weighting is carried out from the weighting between processes, attributes, and criteria. The questionnaire was filled out by an expert, namely the owner of Tempeh crackers SME who knew the supply chain system and the condition of the company. Table 3 shows the weight of each basic process, the weight of each attribute, the weight of each KPI and the performance value of the tempeh cracker SME. 
Table 3. Calculation of the Final Performance of Tempeh Crackers SME

\begin{tabular}{|c|c|c|c|c|c|c|c|c|c|}
\hline No & $\begin{array}{l}\text { Business } \\
\text { Process }\end{array}$ & $\mathbf{A}$ & Attributes & B & $\begin{array}{l}\text { Key Performance } \\
\text { Indicators }\end{array}$ & C & $\mathbf{S}$ & D & $\mathbf{F}$ \\
\hline 1 & \multirow[t]{2}{*}{ Plan } & \multirow[t]{2}{*}{0.44} & Reliability & 0.67 & MUI Halal Label & 1.00 & 0.0 & 0.29 & 0.00 \\
\hline 2 & & & Responsiveness & 0.33 & Meeting with Customers & 1.00 & 0.0 & 0.15 & 0.00 \\
\hline 3 & \multirow[t]{5}{*}{ Source } & \multirow[t]{5}{*}{0.21} & \multirow[t]{2}{*}{ Reliability } & \multirow[t]{2}{*}{0.75} & Halal Raw Materials & 0.83 & 71.4 & 0.13 & 9.34 \\
\hline 4 & & & & & $\begin{array}{l}\text { Order Received Damage } \\
\text { Free }\end{array}$ & 0.17 & 100.0 & 0.03 & 2.68 \\
\hline 5 & & & \multirow[t]{3}{*}{ Responsiveness } & \multirow[t]{3}{*}{0.25} & $\begin{array}{l}\text { Lead time for ordering } \\
\text { materials }\end{array}$ & 0.43 & 91.3 & 0.02 & 2.06 \\
\hline 6 & & & & & $\begin{array}{lll}\text { Accuracy } & \text { Payment } & \text { To } \\
\text { Supplier } & & \\
\end{array}$ & 0.43 & 100.0 & 0.02 & 2.26 \\
\hline 7 & & & & & $\begin{array}{l}\text { Appropriate in Paying } \\
\text { Salaries }\end{array}$ & 0.14 & 100.0 & 0.01 & 0.74 \\
\hline 8 & \multirow[t]{4}{*}{ Make } & \multirow[t]{4}{*}{0.14} & Reliability & 0.52 & $\begin{array}{l}\text { Number } \\
\text { products }\end{array}$ of defective & 1.00 & 33.3 & 0.07 & 2.43 \\
\hline 9 & & & Responsiveness & 0.21 & Production cycle time & 1.00 & 99.8 & 0.03 & 2.93 \\
\hline 10 & & & Agility & 0.15 & $\begin{array}{l}\text { Flexibility in the } \\
\text { manufacture of finished } \\
\text { products }\end{array}$ & 1.00 & 50.0 & 0.02 & 1.05 \\
\hline 11 & & & Asset & 0.12 & Equipment life & 1.00 & 50.0 & 0.02 & 0.84 \\
\hline 12 & \multirow[t]{2}{*}{ Deliver } & \multirow[t]{2}{*}{0.12} & Reliability & 0.67 & $\begin{array}{l}\begin{array}{l}\text { Delivery } \\
\text { products }\end{array} \\
\end{array}$ & 1.00 & 82.6 & 0.08 & 6.64 \\
\hline 13 & & & Responsiveness & 0.33 & Sales timeframe & 1.00 & 100.0 & 0.04 & 3.96 \\
\hline 14 & Return & 0.19 & Reliability & 0.80 & Complain Rate & 1.00 & 60.0 & 0.15 & 9.12 \\
\hline 15 & & & Responsiveness & 0.20 & Replacement & 1.00 & 50.0 & 0.04 & 1.90 \\
\hline
\end{tabular}

Where:

A is weights for Level 1

$\mathrm{B}$ is weights for Level 2

$\mathrm{C}$ is weights for Level 3

$\mathrm{D}$ is Final weights. or A x B x C

$\mathrm{S}$ is SNORM

F is performance based on each KPI. calculated by $\mathrm{S} \times \mathrm{D}$

\subsection{Discussion}

Of the three related references and according to company conditions, 15 KPIs were designed for Tempeh crackers. The KPI is intended to measure the performance of halal production as part of the halal supply chain. Of the $15 \mathrm{KPIs}$ that are directly related to the performance of halal production, namely:

1. MUI halal label

The existence of an MUI halal label on the product indicates that the company has obtained an Halal MUI decree

2. Halal raw material

The use of halal materials is one of the requirements to obtain halal decree.

3. Order received damage free

The absence of damaged materials from suppliers is an indicator of production with halal and thayyib materials

4. Accuracy payment to supplier

Payment on time and in the right amount to suppliers is the implementation of the hadith of the Prophet to hasten payment after work is completed.

5. Appropriate in paying salaries 
Immediate payment to workers is also an implementation of the hadith of the Prophet Muhammad which states to pay labor wages before their sweat dries

6. The number of defective products

The defects in this extended case also include those that do not comply the halal criteria. This is one of the criteria in the halal guarantee system.

Other KPIs are general in nature, not directly related to the halal status of a product. But if the KPI is fulfilled, the halal production performance will also get better. For example, the KPI for changing products to consumers, if done immediately, is an implementation of fulfilling a promise, which is a characteristic of the goodness of a Muslim.

The calculation of SME performance using the SCOR method yields a value of 45.94, so that the performance of SMEs is included in the marginal category [12]. The traffic light system is used to categorize KPIs that need improvement [13]. The traffic light system uses 3 color categories. The red indicator has a score limit of $\leq 60$, given if the KPI does not reach the target or is below the target, so that it needs to be corrected. The yellow color with a score limit of $60<\mathrm{KPI}<80$ indicates that the score achieved needs to be improved. Green color with a KPI score limit $\geq 80$, has an indication that the score achieved is in accordance with the target desired by the company [14]. KPI grouping based on the traffic light system at SME Tempeh Crackers can be seen in Table 4.

Table 4. Grouping KPIs based on the Traffic Light System of Tempeh crackers SME

\begin{tabular}{|c|c|c|}
\hline No & Key Performance Indicators & SNORM \\
\hline 1 & MUI Halal Label & 0,00 \\
\hline 2 & Meeting with Customers & 0,00 \\
\hline 3 & Halal Raw Materials & 71,42 \\
\hline 4 & Order Received Damage Free & 100,00 \\
\hline 5 & Lead time for ordering materials & 91,30 \\
\hline 6 & Accuracy Payment To Supplier & 100,00 \\
\hline 7 & Appropriate In Paying Salaries & 100,00 \\
\hline 8 & Number of defective products & 33,33 \\
\hline 9 & Production cycle time & 99,80 \\
\hline 10 & Flexibility in the manufacture of finished products & 50,00 \\
\hline 11 & Equipment life & 50,00 \\
\hline 12 & Delivery of finished products & 82,60 \\
\hline 13 & Sales timeframe & 100,00 \\
\hline 14 & Complain Rate & 60,00 \\
\hline 15 & Product Replacement Time & 50,00 \\
\hline
\end{tabular}

From Table 4, there are 7 KPIs which are categorized as red which means they need repair. Of the 7 KPIs that need repair, two of them are directly related to the halal status of the product, namely the MUI halal label and the number of defective products, while the halal raw material is yellow. All materials used must be clearly legal and proven by sufficient supporting documents. SMEs should use materials that have a valid Halal certificate. Products that do not meet the halal criteria are also classified as defects. If in the 
production activity or the final product there is contamination with illegal goods, the material / product should be destroyed. The MUI halal label can be applied to the product packaging, if the audit results discussed in the fatwa commission receive a halal decree. Identification of the causes and solutions that can be offered in improving the supply chain management performance of Tempeh crackers SME for other performance indicators which are colored red are

1. Meetings with Customers

This KPI has a score of 0 , because the SME has not planned a schedule to meet customers to listen to consumer complaints about the crackers produced. SME owners can plan a schedule for meetings with consumers, for example, one meeting a month.

2. Equipment Life

This KPI has a score of 50. This occurs because the drying tarpaulin is damaged due to the influence of the sun's heat, and workers are not careful in pulling the drying tarpaulin. Solutions that can be done are: 1) Replacing a better and stronger drying tarpaulin material, 2) SME owners can give instructions to workers in charge of drying them to be more careful when pulling the tarpaulin when drying.

3. Flexibility in Product Manufacturing

This KPI has a score of 50. The reasons for the limited number of products are: 1) Unpredictable drying weather, and 2) The insufficient area of the cracker drying area. The solution: SME owners can increase their cracker production when the weather is good, so that if there is a sudden demand the SME can fulfill the consumer's demand.

4. Complain Rate

This KPI has a score of 60 . The reason: The weather is often rainy so that the drying takes longer time which causes the demand from consumers not to be fulfilled in a timely manner. The solution: Adding tools that can help the drying process faster during the rainy season so that you don't experience production problems.

5. Product Replacement Time

This KPI has a score of 50. The reason: When consumers request a product replacement because the quality has decreased, SMEs cannot immediately replace products because they run out of stock. The solution: Replace plastic packaging with thicker plastic so that the product lifetime lasts longer.

\section{Conclusion}

The conclusions obtained from this research are:

1. From the measurement results using the SCOR method, it is found that the final performance of the tempeh cracker SME is 45.94 which indicates the performance of SME is in the marginal category. KPIs that have red indicators, namely: (1) Meetings with customers, (2) MUI halal labels, (3) Number of defective products, (4) Flexibility in product manufacturing, (5) Equipment life, (6) Complain Rate, (7) Product replacement time.

2. KPIs that are directly related to the halal status of the product of the 15 indicators used are Halal MUI Label, Halal raw material, Order received damage free, Accuracy payment to supplier, Appropriate in paying salaries, and the number of defective products.

3. MUI Halal label and number of defective products are indicators that need repair (red color), while halal raw material is yellow. The use of halal ingredients is an important indicator of the halal status of a product so this should be prioritized for improvement. If the material has been halal and the certification requirements have been met, the MUI halal label can be imprinted on the product. 
This research is supported by the Universitas Sumatera Utara through TALENTA Research with contract number 4142 / UN5.1.R / PPM / 2020 dated April 27, 2020. We would also like to thank colleagues who provide views and expertise related to the research carried out.

\section{References}

1. W. Rachbini, J. Riset Manajemen dan Bisnis, 1, 1 (2016)

2. I. N. Pujawan, M. Er, Supply Chain Management, $2^{\text {nd }}$ ed. (Gunawidya, Surabaya, 2010)

3. M. Ali, J. Ahkam, 16, 2 (2016)

4. Republic of Indonesia, Legislation No. 33 about Halal Product Assurance (2014)

5. LPPOM MUI, retrieved from Daftar Belanja Produk Halal LPPOM MUI Pusat (www.halalmui.org, 2019)

6. M. Tieman, J. G. A. J. van der Vorst, M. C. Ghazali, J. Islamic Marketing, 3, 3 (2012)

7. A.D. Prasetya, D. Retnoningsih, D. Koestiono, J. Habitat, 30, 2 (2019)

8. Harwati, A. N. Y. Pettalolo, Proc. 1st Int. Conf. on Industrial and Manufacturing Eng., 505, 012020 (IOP Conference Series: Material Science and Engineering, Medan, 2019)

9. E. Barlian, Metodologi Penelitian Kualitatif \& Kuantitatif (Sukabina, Padang, 2016)

10. H. Firdaus, D. M. Midyanti, N. Mutiah, J. Coding: Jurnal Komputer dan Aplikasi, 8, 3 (2020)

11. R. Wahyuniardi, M. Syarwani, R. Anggani, J. Ilmiah Teknik Industri, 16, 2 (2017)

12. M. I. Ardhanaputra, J. Integrasi Sistem Industri UMJ, 6, 1 (2019)

13. H. C. Wahyuni, I Vanany, U. Ciptomulyono, Proc. IEEM, (IEEE, Bangkok, 2018)

14. D. A. Putri, N. U. Handayani, J. J@ti Undip : Teknik Industri, 10, 5 (2015) 